\title{
Distribution of HCV Genotypes in Patients of with Chronic Hepatitis $C$ in the Eastern Anatolia Region
}

\author{
Doğu Anadolu Bölgesindeki Kronik Hepatit C Hastalarında HCV Genotiplerinin Dağlımı
}

\author{
Osman AKTAŞ1, Ahmet ÖZBEK2, Hakan AYDIN3, Mehmet Beyhan ÖZKÜLEKCl1 \\ ${ }^{1}$ Atatürk University Faculty of Medicine, Department of Medical Microbiology, Erzurum, Turkey \\ 2Sakarya University Faculty of Medicine, Department of Medical Microbiology, Sakarya, Turkey \\ ${ }^{3}$ Atatürk University Faculty of Veterinary Medicine, Department of Virology, Erzurum, Turkey
}

\begin{abstract}
Objectives: Hepatitis $C$ is a blood-borne virus affecting a large number of people all over the world. Hepatitis $\mathrm{C}$ virus $(\mathrm{HCV})$ is one of the important causative agents of chronic hepatitis, cirrhosis, and hepatocellular carcinoma. Its viral genotypes variability affects response to interferon treatment. Therefore, identification of viral genotypes is key to management and treatment of hepatitis $C$ infection. In our region, there has been no study on genotyping of the virus yet. This study was designed to determine the prevalence of HCV genotypes in our region.

Materials and Methods: This study was conducted on the serum specimens of patients with chronic hepatitis $\mathrm{C}$ in the provinces of the Eastern Anatolia Region who attended Atatürk University between January 2011 and February 2014. Anti-HCV antibodies in the serum specimens were identified using an enzyme immunoassay kit (Dia. Pro Diagnostic Bioprobes Srl, Milan, Italy) and automatic analyzer, (Radim/ Alise ${ }^{\circledR}$, Calenzano-Firenze, Italy). HCV-RNA load was detected by quantitative PCR (Qiagen ${ }^{\circledR}$, Germany). HCV genotypes were determined by pyrosequencing method using Pyromark 024 kit and automatic analyzer (Qiagen ${ }^{\odot}$, Germany).

Results: Four different HCV subgenotypes including $1 \mathrm{~b}(87.0 \%)$, 1a (8.3\%), 3a (3.7\%) and $4 \mathrm{~d}(1 \%)$ have been identified in seven different provinces within the Eastern Anatolia Region. Genotype 1 was found to be the most common major genotype. Conclusion: The prevalence of HCV genotypes in patients in the Eastern Anatolia Region was reported for the first time. We assume that the results obtained from this study may contribute to regional epidemiological data on HCV genotypes and to the treatment strategies for patients with hepatitis $\mathrm{C}$ in our region. (Viral Hepatitis Journal 2014; 20(3): 91-94)
\end{abstract}

Key words: Hepatitis C virus, Anti-Hepatitis C Virus, Hepatitis C Virus genotypes, enzyme immunoassay, quantitative PCR, pyrosequencing

Conflict of interest: The authors reported no conflict of interest related to this article.

\section{ÖZET}

Amaç: Hepatit $\mathrm{C}$ virüsü (HCV) kan yoluyla bulaşan, tüm dünyada geniş kitleleri etkileyen, kronik hepatit, siroz ve hepatoselüler karsinom gibi hastalıkların önemli etkenlerinden biridir. Hepatit $C$ virüsünün genotipik değişkenliği hepatit $C$ hastalarının takibinde ve tedavisinde yol gösterici olmaktadır. Daha önce Doğu ve Kuzey-Doğu Anadolu bölgesi hastalarında hepatit $C$ virüs genotiplendirilmesiyle ilişkili bir sonuç verilmemiş̧tir. Bu çalışma, yöremizdeki hastalarda hepatit $C$ virüs genotip prevalansının belirlenmesi amacıyla planlanmıştı.

Gereç ve Yöntemler: Bu çalışma Doğu Anadolu bölge illerinden Ocak 2011-Şubat 2014 tarihleri arasında Atatürk Üniversitesi Araştırma Hastanesine başvuran kronik hepatit $C$ hastalarının serum örnekleri üzerinde gerçekleştirilmiştir. AntiHCV antikorları enzim immunoassay kitleri (Dia. Pro Diagnostic Bioprobes Srl, Milano, Italy) ile otomatik analizörde (Radim/Alisei® ${ }^{\circledR}$, Calenzano-Firenze, Italy); HCV-RNA yükü kantitatif PCR (Qiagen ${ }^{\odot}$, Germany) ile araştırıldı. HCV genotipleri pirosekanslama yöntemi ile (Pyromark 024 kit, Qiagen ${ }^{\circledR}$, Germany) kitleri ve otomatik analizörü kullanılarak araştırımışıtır.

Bulgular: Bu çalışmada, Doğu Anadolu bölgesi sınırları içindeki yedi farkı ilde yaşayan kronik hepatit C'li olgularda $1 \mathrm{~b}(\% 87,0)$, 1a $(\% 8,3)$, 3a $(\% 3,7)$ ve $4 \mathrm{~d}(\% 1)$ olmak üzere dört farkı HCV subgenotipi tespit edilmiştir. Bölgemizde en yaygın ana genotipin genotip 1 olduğu görülmüştür.

Sonuç: Doğu Anadolu illerindeki kronik hepatit C'li hastalarda HCV genotiplerinin prevalansı ilk kez bildirilmiştir. Bu çalışmanın, HCV genotiplerine ilişkin bölgesel epidemiyolojik verilere ve bölgemizdeki HCV'li hastaların tedavi stratejilerinin belirlenmesine katkı sağlayacağını düşünüyoruz. (Viral Hepatit Dergisi 2014; 20(3): 91-94)

Anahtar kelimeler: Hepatit C virüsü, Anti-Hepatit C Virüsü, Hepatit C Virüsü genotipleri, enzim immunoassay, kantitatif PCR, pirosekanslama

Çıkar çatışması: Yazarlar bu makale ile ilgili olarak herhangi bir çıkar çatışması bildirmemişlerdir. 


\section{Introduction}

Hepatitis $\mathrm{C}$ virus ( $\mathrm{HCV}$ ) is a member of the genus Hepacivirus in the Flaviviridae family. It causes various important clinical pictures such as chronic hepatitis, cirrhosis and hepatocellular carcinoma (1). Approximately 200 million people in the world are infected with $\mathrm{HCV}$ and are at risk of developing above cited diseases. It has been suggested that HCV-associated end-stage liver disease and/ or hepatocellular carcinoma account for more than half of adult liver transplantation cases in Western countries, and that HCVassociated diseases is expected to exponentially increase in the near future (2). The natural course of hepatitis $C$ virus infection varies from person to person. It has been stated that approximately $20-30 \%$ of infected persons get rid of the virus from their bodies in the acute phase, and the remaining of infected persons may develop chronic hepatitis which could progress to cirrhosis and liver cancer in 20-30 years (3). The current treatment for HCV infection is made by administration of PEG-interferon- $\alpha$ in combination with ribavirin (RBV). A favorable response to this treatment is achieved in about $50 \%$ of patients (4).

$\mathrm{HCV}$ is a single-stranded positive-sense virus with a genomic RNA molecule approximately 9.600 nucleotides in length. There are significant differences in nucleotide and amino acid sequences in the different regions of the HCV genome. This heterogeneous virus is divided into six major genotypes and about 80 subtypes, according to the mutational differences from the reading, lack of RNA polymerase (5). The prevalence of predominant genotypes is varied in HCV-infected people living in different geographies. The most common genotypes are 1, 2 and 3 throughout the world. HCV subtypes $1 \mathrm{a}$ and $1 \mathrm{~b}$ are common in the US and Europe. In Japan, genotype $1 \mathrm{~b}$ is responsible from approximately $1 / 4$ of HCVinfected patients. Genotypes $2 \mathrm{a}$ and $2 \mathrm{~b}$ are relatively common in North America, Europe and Japan, and genotype 2c is found commonly in Northern Italy. HCV genotype 4 has been reported to be prevalent in North Africa and the Middle East, and genotypes 5 and 6 in South Africa and Hong Kong (6). It has been reported that $\mathrm{HCV}$ prevalence was between $2 \%$ and $3 \%$ in the world and between $1 \%$ and $1.9 \%$ in Turkey, but genotype 1 is most common (68-94\%) and least responsive to current therapies (7).

Clinical course of the disease, response to treatment in HCVinfected patients varies depending on HCV genotypes. As an example, individuals with genotype $1 \mathrm{~b}$ are less likely to respond well to IFN treatment, besides, the risk of developing hepatocellular carcinoma is high (8). This study is planned to contribute to the determination of the treatment process and to the treatment strategies by identifying the HCV genotypes in infected patients in our region.

\section{Materials and Methods}

\section{Patients}

This study was conducted on serum specimens of 108 patients (59 males, 49 females; median age: 50.6 years; range:2076 years) admitted to Atatürk University Research Hospital one of the provinces of the Eastern Anatolia Region between January 2011 and February 2014.

\section{Serologic Tests}

Anti-HCV antibodies in the serum specimens were investigated using an enzyme immunoassay kit (Dia. Pro Diagnostic Bioprobes
Srl, Milano, Italy) and automatic analyzer, (Radim/Alisei ${ }^{\circledR}$, CalenzanoFirenze, Italy) according to the manufacturer's recommendations.

\section{Purification of Hepatitis C Virus-RNA and PCR}

Hepatitis C Virus-RNA was purified by QIAsymphony DSP Virus/Pathogen Midi Kits (Qiagen, Germany) from $1000 \mu \mathrm{L}$ of serum specimens taken from each patient.

$\mathrm{PCR}$ reaction was used in the amplification of $\mathrm{HCV}$ core and 5 'UTR regions that are very well protected for genotyping. In the RNA samples, cDNA and PCR reaction of these two regions was performed by a one-step RT-PCR. QIAGEN PyromarkOneStep RT-PCR Kit (Qiagen, Germany) was used in the reaction. PCR-1 and PCR-2 reaction mixes (5X RT-PCR buffer $10 \mu \mathrm{L}$, dNTP $2 \mu \mathrm{L}$, HCV primer pair $2 \mu \mathrm{L}, \mathrm{RT}-\mathrm{PCR}$ enzyme mix $2 \mu \mathrm{L}$, water $29 \mu \mathrm{L}$ and template RNA $5 \mu \mathrm{L}$ ) for two different regions of the HCV genome to be be amplified were prepared according to the manufacturer's protocol. PCR cycles: $50{ }^{\circ} \mathrm{C}$ for 30 minutes 1 cycle (reverse transcription), $95^{\circ} \mathrm{C}$ for 15 minutes 1 cycle (HotStarTaq DNA Polymerase activation), $94{ }^{\circ} \mathrm{C}$ for 30 seconds, $58{ }^{\circ} \mathrm{C}$ for 30 seconds, $72{ }^{\circ} \mathrm{C}$ for 30 seconds 45 cycles and finally 1 cycle 10 minutes at $72{ }^{\circ} \mathrm{C}$ (final extension). The same temperature cycles were used in both PCR reactions. Amplification products of different portions of the HCV genome (240 bp in PCR-1 and $180 \mathrm{bp}$ in PCR-2) were obtained at the end of the reaction. The products were kept on ice packs ready to be used as template for sequenced.

\section{HCV Genotyping}

In pyrosequencing analysis, Pyromark Q24 (Qiagen ${ }^{\odot}$ ) devices and kits were used. Four different sequencing primers ( $\mathrm{HCV}$ S1, S2, S3 in PCR-1 and HCV-S4 in PCR-2) were used for the sequencing process. Immobilization of PCR-1 and PCR-2 products was achieved by binding to sepharose streptavidin coated beads $(2 \mu \mathrm{L})$ in binding buffer $(40 \mu \mathrm{L})$ and ultrapure water $(28 \mu \mathrm{L})$. Subsequently, single-stranded DNAs were obtained by incubating in $70 \%$ ethanol for 5 seconds, in denaturation solution for 5 seconds, and in the wash solution for 10 seconds. Then, the DNAs were incubated at $80^{\circ} \mathrm{C}$ for 2 minutes in solution plates containing four sequencing primers. After this preparation, plates containing sequencing primers that were hybridized with DNA were placed in pyrosequencing device. At the end of the process, the results from the process pyrosequence were evaluated in comparison with databases (HCV database: http://hcv.lanl.gov).

\section{Results}

As seen in Table 1, four different HCV subgenotypes belonging to three major genotypes were detected in a total of $108 \mathrm{HCV}$ RNA-positive cases. The most common subgenotype was found to be $1 \mathrm{~b}$ in our region, as is the case with throughout Turkey.

The distribution of HCV genotypes in patients from the provinces of the Eastern Anatolia Region is shown Table 2. The genotypes distributed as 1a, 1b, 3a and $3 \mathrm{~b}$ in Erzurum; $1 \mathrm{a}, 1 \mathrm{~b}$ and $3 a$ in Ağrı; 1b and 3a in Iğdır; $1 \mathrm{a}$ and $1 \mathrm{~b}$ in Erzincan, and only $1 \mathrm{~b}$ in the others.

\section{Discussion}

The prevalence of HCV genotypes varies among human living in different geographical regions. The number of studies on the distribution of $\mathrm{HCV}$ genotypes in our country started from the middle of the 1990s and 2000s to the present day has increased steadily. Genotype 1 is common in all regions of our country. 


\begin{tabular}{|l|l|l|}
\hline $\begin{array}{l}\text { Table 1. Distribution of Hepatitis C Virus (HCV) genotypes in patients } \\
\text { with chronic hepatitis C in our region }\end{array}$ \\
\hline Genotypes & $\mathbf{n}$ & $\%$ \\
\hline $1 \mathrm{~b}$ & 94 & 87.0 \\
\hline $1 \mathrm{a}$ & 9 & 8.3 \\
\hline $3 \mathrm{a}$ & 4 & 3.7 \\
\hline $4 \mathrm{~d}$ & 1 & 1.0 \\
\hline Total & 108 & 100.0 \\
\hline
\end{tabular}

\begin{tabular}{|l|l|l|l|l|l|}
\hline $\begin{array}{l}\text { Table 2. Distribution of Hepatitis C Virus (HCV) genotypes in patients } \\
\text { from the provinces of Eastern Anatolia region }\end{array}$ \\
\hline Cities & $\mathbf{n}$ & 1a & 1b & 3a & 4d \\
\hline Erzurum & 69 & $7(10.14)$ & $60(86.96)$ & $1(1.45)$ & $1(1.45)$ \\
\hline Iğdır & 14 & - & $12(85.7)$ & $2(14.3)$ & - \\
\hline Ağrı & 9 & $1(11.1)$ & $7(77.8)$ & $1(11.1)$ & - \\
\hline Erzincan & 6 & $1(16.7)$ & $5(83.3)$ & & - \\
\hline Kars & 6 & - & $6(100.0)$ & - & - \\
\hline Muş & 3 & - & $3(100.0)$ & - & - \\
\hline Tunceli & 1 & - & $1(100.0)$ & - & - \\
\hline
\end{tabular}

Data presented as $\mathrm{n}(\%)$ of patients

In Izmir, which is one of the provinces of the Aegean Region, Abacioglu and colleagues, found in 2005 that the predominant genotype was 1b (75.3\%), followed by 1a (19.1\%) 2 (3.4\%), and 4 (2.2\%) (9). They also reported that distribution of HCV genotypes in patients with chronic liver disease were affected by various factors such as age, gender, blood transfer history, and alanine aminotransferase (ALT) levels. In a study conducted in lzmir, in 2001, Özacar and colleagues (10) reported that genotype 1b was observed in $81.2 \%$ of subjects with chronic hepatitis, genotype $1 \mathrm{a}$ in $10.0 \%$, genotypes $2 \mathrm{a} / 2 \mathrm{c}$ in $1.8 \%$, genotype $3 \mathrm{a}$ in $0.6 \%$, genotype $4 c / 4 d$ in $0.6 \%$, and mixed genotype was observed in $4.7 \%$ of patients with chronic hepatitis. Erensoy and colleagues (11) also found the prevalence of $66.6 \%$ of genotype $1 \mathrm{~b}$ and 33.3 genotype 1a, in district Izmir, in 2002. Altuglu and colleagues (12), in another study conducted in Izmir, in 2008, reported that they identified genotype $1 \mathrm{~b}$ in $87.2 \%$ of patients, genotype $1 \mathrm{a}$ in $9.9 \%$, genotype 3 in $1.4 \%$, genotype 2 in $0.9 \%$ and genotype 4 in $0.6 \%$ of subjects. The prevalence of HCV genotypes has been reported from different provinces of the Aegean Region. In their study including 100 subjects in Manisa, in 2009, Sanlidag and colleagues (13) reported that genotype $1 \mathrm{~b}$ was determined in 90 patients $(90 \%)$, genotype $4 a$ - in five patients $(5 \%)$, genotype $1 \mathrm{a}$ - in two patients (2\%) and genotype $2 \mathrm{a}$ - in two patients $(2 \%)$. In Afyonkarahisar, in 2009, Çiftçi and colleagues (14) found genotype 1 in $91.2 \%$ of individuals and genotype 4 in $8.8 \%$. Kalaycl and colleagues (15) found genotype 1b, 1a, 4 and 1c in $63.3 \%, 20 \%$, $13.3 \%$, and $3.3 \%$ of patients, respectively. In a study conducted in Ankara, in the Central Anatolia Region, on 365 patients with chronic hepatitis C, Bozdayi and his colleagues (16) determined genotype $1 \mathrm{~b}$ in $84 \%$ of cases, $1 \mathrm{a}$ - in $11 \%, 2$ in $3 \%$ and genotype 3 and 4 - in $1 \%$ of subjects. They have also reported that among 36 patients receiving hemodialysys, 28 (78\%) had genotype $1 \mathrm{~b}$ and the rest (22\%) had genotype 1a. In Kayseri, in 2011, Gökahmetoğlu et al. (17) detected genotype 1, genotype 4 and genotype 2 in 90
(61.7\%) 52 (35.6\%), and 4 (2.7\%) patients, respectively. In Konya, in a study by Ural et al. (18) all patients with hepatitis $C(n=80)$ were found to have genotype $1 \mathrm{~b}$. In another study from the Central Anatolia Region, Çelik et al. (19), reported genotype $1 \mathrm{~b}$ in $88.2 \%$, genotype $1 \mathrm{a}$ in $9.0 \%$, genotype $2 \mathrm{a}$ in $1.1 \%$ and genotype 3 in $1.7 \%$ of HCV isolates from infected cases in 2010 in Sivas.

In a study from Zonguldak, a city in the Black Sea Region, evaluating the HCV genotype profiles of patients with chronic hepatitis $C$ in 2010, Aktaş et al. (20) reported that $97.4 \%$ of patients had genotype $1 \mathrm{~b}$ and $2.6 \%$ had genotype $1 \mathrm{a}$. In another study from the Black Sea Region, Buruk et al. (21) reported genotype 1b $(87.5 \%)$ as the most prevalent genotype in the Black Sea provinces followed by genotypes 1a (5.3\%), 2 (1.6\%), 3 (4.9\%) and 4 (0.7\%).

In a study from Diyarbakır, a city in the Southeast Anatolia Region, Yarkın and Hafta (22) reported in 2000 that genotype 1 was most common, accounting for $82.2 \%$ of infections. Genotype 1 a was detected in $14.5 \%$ and genotype $2 a$ in $3.3 \%$ of subjects genotype 2a. In the same province in 2009, Özbek et al. (23) have reported that genotype $1 \mathrm{~b}$ was most common, accounting for $87.8 \%$ of infections, followed by 2,3 and $3 a(2.7 \%, 2.7 \%$, $2.7 \%$, respectively. In Gaziantep, Karslıgil et al. (24) detected five genotypes (1b (78.4\%), 1a (9.8\%), 2 (7.8\%), $3(2.0 \%)$ and $4(2.0 \%))$ in 51 patients with hepatitis C. More recently (in 2013), Kirişçi et al. (25) detected genotype 1 in 60\%, genotype 2 in $40 \%$ of 100 patients infected with HCV in Kahramanmaraş.

In the Marmara Region, in their study conducted in 2010 in Istanbul Kücüköztaş and colleagues (26) detected six genotypes (1b, 3a, 4e, 2a/2c, 1a and 4) in 52 patients with chronic hepatitis C and they stated that the most prevalent genotype was b1 (76.9\%). Altındiş and et al. (27) identified genotype $1 \mathrm{~b}$ in $92.4 \%$, genotype $1 \mathrm{a}$ in $5.7 \%$, and genotype 2 in $1.9 \%$ of soldiers in the Northern Cyprus in 2006.

According to the studies mentioned above, HCV genotypes in our country were distributed approximately range from 60 to $100 \%$ for $1 b, 2$ to $30 \%$ for $1 a, 1$ to $8 \%$ for 2,1 to $10 \%$ for 3 , and 2 to $36 \%$ for 4 . In our study, four different HCV subgenotypes (1a, 1b, $3 a$ and $4 d$ ) belonging to three major genotypes (1, 3 and 4) were detected in a total of $108 \mathrm{HCV}$ RNA-positive cases from the seven provinces of the Eastern Anatolia Region. The most common subgenotype was found to be $1 b$, as is the case throughout Turkey. The genotypes were distributed as $1 \mathrm{a}, 1 \mathrm{~b}, 3 \mathrm{a}$ and $3 \mathrm{~b}$ in Erzurum; $1 a, 1 b$ and $3 a$ in Ağrı; $1 b$ and $3 a$ in Iğdır; $1 a$ and $1 b$ in Erzincan and only $1 \mathrm{~b}$ in the other cities. The number of different genotypes is most probably affected by the low number of cases in other provinces, except in Erzurum. Only genotype 4 was found to be lower than the average in Turkey.

As shown, in all of the studies done in our country has determined that $1 \mathrm{~b}$ is the most prevalent genotype among the genotypes of HCV in patients with hepatitis C. However, we have observed that the distribution of the genotypes varies significantly in other countries. In 2011, Sievert and colleagues (28) reported that genotype 1 was common in Australia, China, Taiwan and other North Asian countries; genotype 6 in Vietnam and other Southeast Asian countries; genotype 3 in India and Pakistan; genotype 4 in the Middle Eastern countries such as Egypt, Saudi Arabia and Syria.

RBV in combination with pegylated interferon $\alpha$ (PEG-IFN- $\alpha$ ) is recommended for standard treatment of chronic hepatitis $C$ infection $(29,30,31)$. This combination therapy has greatly improved the sustained virological response rate, particularly in difficult-to- 
treat cases. Determination of sustained virological factors such as, host, virus and treatment-related factors provides important information about the mechanisms of action of RBV and IFN $\alpha$. So far, a large number of permanent and non-permanent important determinants have been identified for the treatment of hepatitis C (30). Elderly, cirrhosis or advanced fibrosis, excess weight, obesity, diabetes, lowlevels of ALT, cholesterol, hemoglobin and platelets, insulin resistance, and the level of hepatic steatosis are the important factors associated with host. In addition, among the main factors associated with the virus are HCV genotype, pretreatment viral load and the first virological response. Treatment dose of RBV and PEG-IFN- $\alpha$ is an important factor for treatment. Antiviral therapy is administered for 48 weeks in patients infected with genotype 1 and 4 and the number of viruses in the blood decreases within 24 weeks. Genotype 2 or 3 is more sensitive to combination therapy of RBV and PEG-IFN- $\alpha$ than genotype 1 or 4, allowing shorter duration of treatment (24 weeks) (30).

As a result, the frequency of the HCV genotypes in patients with chronic hepatitis $\mathrm{C}$ in the Eastern Anatolia Region is consistent with that of Turkey except for genotype 4 with a low rate. We think that the results of this regional study will contribute to the national epidemiological data.

\section{References}

1. Hazari S, Taylor L, Haque S, Garry RF, Florman S, Luftig R, Regenstein F, Dash S. Reduced expression of Jak-1 and Tyk-2 proteins leads to interferon resistance in Hepatitis $C$ virus replicon. Virol J. 2007; 4: 89.

2. Quer J, Buti M, Cubero M, Guardia J, Esteban R, Esteban JI. New strategies for the treatment of hepatitis $C$ virus infection and implications of resistance to new direct-acting antiviral agents. Infect Drug Resist. 2010; 3: 133-145.

3. Nwankiti OO, Ndako JA, Echeonwu ONG, Olabode AO, Nwosuh $\mathrm{Cl}$, Onovoh EM, Okeke LA, Akinola JO, Duru BN, Nwagbo IO, Agada GO, Chukwuedo AA. Hepatitis C Virus infection in apparentenly healthy individuals with family history of diabetes in Vom, Plateau State Nigeria. Virol J. 2009; 6: 110.

4. Buck M. Direct Infection and Replication of Naturally Occurring Hepatitis C Virus Genotypes 1, 2, 3 and 4 in Normal Human Hepatocyte Cultures. PLoS ONE. 2008; 3(7):2660.

5. Gonzalez-Candelas F, Lopez-Labrador FX, Bracho MA. Recombination in hepatitis C virus. Viruses. 2011; 3(10): 2006-2024.

6. Idrees $M$, Riazuddin S. Frequency distribution of hepatitis $C$ virus genotypes in different geographical regions of Pakistan and their possible routes of transmission. BMC Infect Dis. 2008; 8: 69.

7. Barut HŞ, Günal Ö. Global and National Epidemiology of Hepatitis C. Klimik Derg. 2009; 22(2): 38-43.

8. Usluer G. Diagnosis in Chronic Hepatitis. Ankem Derg 2006; 20 (Ek 2): 200-202.

9. Abacioglu YH, Davidson F, Tuncer S, Yap PL, Ustacelebi S, Yulug $\mathrm{N}$, Simmonds $\mathrm{P}$. The distribution of hepatitis $\mathrm{C}$ virus genotypes in Turkish patients. J Viral Hepat. 1995; 2(6): 297-301.

10. Özacar T, Altuğlu I, Zeytinoğlu A, Sayıner AA, Akarca U, Erensoy $\mathrm{S}$, et al. Kronik C Hepatitinde HCV genotiplerinin dağılımı. Mikrobiyol Bul. 2001; 35(3): 451-8.

11. Erensoy S, Göksel S, Akarca US, Özkahya M, Canatan D. Hepatit $C$ virüsün polimeraz zincir reaksiyonu ürünlerinin doğrudan dizi analizi ile genotiplendirilmesi. Flora. 2002; 7(2): 104-111.

12. Altuglu I, Soyler I, Ozacar T, Erensoy S. Distribution of hepatitis $C$ virus genotypes in patients with chronic hepatitis $C$ infection in Western Turkey. Int J Infect Dis. 2008; 12(3): 239-244.
13. Sanlidağ T, Akçali S, Ozbakkaloğlu B, Ertekin D, Akduman E. Distribution of hepatitis $C$ virus genotypes in Manisa region, Turkey. Mikrobiyol Bul. 2009; 43(4): 613-618.

14. Çiftçi IH, Er H, Aşık G, Aktepe OC, Altındiş M. Hepatit C virusu (HCV) RNA pozitif olgularda genotip dağılımı. Kocatepe Tıp Derg. 2009; 10(1-2-3): 21-24

15. Kalayci R, Altindiş M, Gülamber G, Demirtürk N, Akcan $Y$, Demirdal T. Genotype distribution of chronic hepatitis B and hepatitis $C$ patients and investigation of the resistance patterns in hepatitis B cases. Mikrobiyol Bul. 2010; 44(2): 237-243.

16. Bozdayı AM, Aslan N, Bozdayı G, Türkyılmaz AR, Şengezer T, Wend U, Erkan O, Aydemir F, Zakirhodjaev S, Orucov S, Bozkaya H, Gerlich W, Karayalçin S, Yurdaydin C, Uzunalimoğlu $\mathrm{O}$. Molecular epidemiology of hepatitis $B, C$ and $D$ viruses in Turkish patients. Arch Virol. 2004; 149(11): 2115-2129.

17. Gökahmetoğlu S, Atalay MA, Kılınç A. Hepatit C virüs genotiplerinin pirosekanslama yöntemi ile belirlenmesi. Erciyes Tip Derg. 2011; 33(2):99-102.

18. Ural O, Arslan U, Fındık D. Konya bölgesinde Hepatit C virusu genotip dağılımı. Infeks Derg. 2007; 21(4): 175-181.

19. Çelik C, Bakıcı MZ, Kaygusuz R, Ertürk R. Sivas yöresindeki HCV genotip dağılımlarının araştırılması. Vir Hep Derg. 2010; 16(3): 106-110.

20. Aktaş E, Ogedey ED, Külah C, Beğendik Cömert F. Hepatitis $C$ virus genotypes in a province of western Black-Sea region, Turkey. Mikrobiyol Bul. 2010; 44(4): 647-650.

21. Buruk CK, Bayramoğlu G, reis A, Kaklıkkaya N, Tosun I, Aydın F. Determination of hepatitis $C$ virus genotypes among hepatitis $\mathrm{C}$ patients in Eastern Black Sea Region, Turkey. Mikrobiyol Bul. 2013: 47(4): 650-657.

22. Yarkın F, Hafta A. Kronik hepatit $C$ infeksiyonu olan hastalarda hepatit C virus genotiplerinin dağılımı. Vir Hep Derg. 2000; 6(3): 164-167.

23. Özbek E, Özekinci T, Meşe S, Atmaca S. Hepatitis C virus genotypes are changing in the southeast of Turkey. Biotechnol \& Biotechnol Eq. 2009; 23(4): 1521-1523.

24. Karslıgil T, Savaş E, Savaş MC. Hepatit $C$ virüsü genotip dağılımı ve 5'UTR nükleotid değişiklikleri. Balkan Med J. 2011; 28(3): 232-236

25. Kirisçci Ö, Çalışkan A, Koçtürk SA, Erdoğmuș P, Gül M. Kahramanmaraş ili hepatit $C$ virüs ile enfekte bireylerde genotip dağılımı ve genotipin HCV-RNA yükü ve ALT-AST ilişkisi. Viral Hepatit Derg. 2013; 19(2): 67-70.

26. Kücüköztaş MF, Ozgunes $N$, Yazici $S$. Investigation of the relationship between hepatitis $\mathrm{C}$ virus $(\mathrm{HCV})$ genotypes with HCV-RNA and alanine aminotransferase levels in chronic hepatitis C patients. Mikrobiyol Bul. 2010; 44(1): 111-115.

27. Altindis $M$, Yilmaz $S$, Dikengil $T$, Acemoglu $H$, Hosoglu $S$. Seroprevalence and genotyping of hepatitis B, hepatitis C and HIV among healthy population and Turkish soldiers in Northern Cyprus. World J Gastroenterol. 2006; 12(42): 6792-6796.

28. Sievert W, Altraif I, Razavi HA, Abdo A, Ahmed EA, Alomair A, Amarapurkar D, Chen $\mathrm{CH}$, Dou X, El Khayat H, Elshazly M, Esmat G, Guan R, Han KH, Koike K, Largen A, McCaughan G, Mogawer S, Monis A, Nawaz A, Piratvisuth T, Sanai FM, Sharara Al, Sibbel S, Sood A, Suh DJ, Wallace C, Young K, Negro F. Systematic review of hepatitis $C$ virus epidemiology in Asia, Australia and Egypt. Liver Int. 2011;31(Suppl 2): 61-80.

29. Khalid O, Bacon BR. Management of the treatment-experienced patient infected with hepatitis $C$ virus genotype 1: options and considerations. Clin Liver Dis. 2011; 15(3): 573-583.

30. Tsubota A, Fujise K, Namiki Y, Tada N. Peginterferon and ribavirin treatment for hepatitis $C$ virus infection. World J Gastroenterol. 2011; 17(4): 419-432.

31. Vermehren J, Sarrazin C. New hepatitis C therapies in clinical development. Eur J Med Res. 2011; 16(7): 303-314. 